\title{
Understanding language and culture in the context of becoming a global citizen: A focus on African Languages
}

\author{
Miidzo Mavesera \\ Research Fellow - University of South Africa \\ maveseram@gmail.com
}

\begin{abstract}
While globalization seems to be the buzz word and an unavoidable ubiquitous phenomenon, it has mainly taken an economic face while other pillars of development lag behind. A distinct area is the social tolerance particularly language and culture. Cultural exchange programs have remained beneficial to satisfy tourist anxieties. The nagging question is, are world systems linked to accommodate citizens from different linguistic and cultural backgrounds? If so, why do we continue to promote certain languages at the expense of others? What needs to be done? Why should we promote indigenous languages? How best can it be done? This paper attempts to unravel the issue of sustainable globalization from the lenses of a language planner focusing on empowering African languages. In the discussion, it is argued that sustainable globalization should include soft issues of development like language planning because language is the soul of any community.
\end{abstract}

Key terms: Language, culture, globalization, global citizen

\section{Introduction}

$\mathrm{T}$ he urge to remain in touch and in control of the global space is not only a concern for economists, giants of commerce and industry but it is also a concern for linguists and civic leaders. In this article, we discuss the role of language in appreciating and participating in the socio-economic and political developments of the global village. Questions like what language is suitable for communicating important information and whose culture is relevant in the global environment emerge. Do African languages have any space in the socio-economic and political lives in the African continent and the universe? In responding to these pertinent questions the discussion takes a holistic approach to sustainable development. The approach helps us to view development from different perspectives that contribute to integral and or well-oiled global development. No part is left behind so when it comes to being a global citizen from a linguistic perspective all languages are viewed as integral components of the world linguistic map. 
Globalization is in turn not limited to economic or commercial development rather it refers to development in every sector.

In the ensuing discussion, terms like language, culture, globalization and global citizen will be defined to guide our line of argument. The paper proceeds to lay the background of the language issue in Africa with specific examples from the Zimbabwean experience.

\section{Definitions}

While key terms to this discussion may be defined in a variety of ways, in this discussion, the terms shall be defined as follows:

Language is a system of words used in a speech community by people in naming the world around them, their interaction with nature and with each other in the process of production of goods and services necessary for their survival.

Culture is the world around a people: it is a way of viewing social reality that is influenced by environment and time. It is the social practices that differentiate one community from the other and at times one generation from the other.

\section{Globalization}

Globalization is a fluid concept that requires unpacking but in this article, it refers to a system of interaction among countries of the world in pursuit of sustainable global socioeconomic development. Roy-Campbell (2006 p.1) has simplified globalization to mean, 'the world getting smaller'. Globalization in the context of this paper refers to the ability of local languages to expand their spheres of influence to communicate important knowledge on the global market place, expressing modern scientific and technological information for the eradication of inequalities and inequities among people of the world.

\section{Global citizen}

A global citizen is a person who cares appreciates and cares about issues of development beyond the personal, national to the global level. The appreciation comes as a result of clear understanding of the interdependence and integration of systems of the world at every developmental stage.

\section{Globalization and African languages}

Globalization as a concept exposes African languages to stiff competition on the international language market as:

- subjects of study;

- media of educational instruction; and

- communication tools in a modern 'technologized' knowledge economy. 
While globalization increases the visibility of African languages beyond the African continent it presents a stiff power game for all languages of the world. In the linguistic power game, languages that are used in critical information delivery such as media of educational instruction and wider communication are the languages of hegemony and power. Globalization and the knowledge economy require quick and critical thinking which is inward looking. Only those with relevant information can effectively contribute towards critical thinking and global development. Relevant information should not be packaged in a language that is not understood by the interlocutors. Language is a critical pillar in the knowledge economy since it underlines and is the king pin in all other pillars of the knowledge economy. It can therefore be claimed that:

No language no communication,

No communication no education,

No education no development,

No development no globalization.

Uju (2008) reasons that; inability to express one-self closes all avenues of individual and collective effective language use as a requirement in the global economy. To become a global citizen one requires a clear appreciation of the historical, geo-political and socioeconomic developments in the world. That appreciation will induce critical thinking in tackling challenges and opportunities that may arise at any given time.

\section{Background and Review of Related Literature}

The colonization of Africa brought with it not just economic and political hegemony but also resulted in the loss of indigenous languages. The loss of a language impacts on people's ability to earn a living (Muindi, 2002), because languages express the needs and concerns that cement the unique identity particular to a group. Language is vital in forming the group's cultural identity; identity gives the group confidence and motivation to engage in economic production. The role of language has been aptly presented by Skutnabb-Kangas (1998 p.13) who reasons that English is an instrument of imperialism in developing countries. Although all African countries have achieved political independence they are still dependent on their former colonial masters in areas of socioeconomic and even political development.

The language of educational instruction is usually the language of commerce and industry. Prah (1995 a, b) and Skutnabb-Kangas (2000) argue that development in Africa will not be forthcoming until we start using African languages as languages of instruction from beginning to end of the education process. There is a very close relationship between economic activity and language especially the language of educational instruction. On the other hand, Anyidoho (1992) emphasizes that no people can despise their own language, customs and institutions and avoid national death. It is against this background that the role of African languages in the African systems of 
education continues to unfold. In spite of Africa attaining political freedom the continent remains under the bondage of socio-economic imperialism.

This situation has a strong bearing on the socio-economic and political status of Africans in the global space. Political freedom without economic freedom is like flying the national flag at half-mast. The state is there but it is in a state of mourning. The nation is there but has no national anthem to bind its citizens together. Referring to the importance of language, Gandhiji in Mutasa, (2006 pp.88-89) argues that;

Our language is a reflection of ourselves and if it is said that our languages are too poor to express the best thought then the sooner we are wiped out of existence the better for us. You enrich your language only if you love and respect it. To develop a language and stick to the false notion that English alone can express our thoughts or transmit them, then there is no doubt that we shall continue to be slaves for all time. With little effort, we can impart knowledge of even the new science through the mother tongue. It is our mental slavery that makes us feel that we cannot do without English.

Is it not an amazing paradox that Africa pays a deaf ear to the language issue yet it is very alert to political jargon like regime change? If language is the soul of a nation and nation states have no confidence in doing business in their indigenous languages then such nations remain slaves in perpetuity. While talking about the language of literature, Ngugi (1994 p.24) questions, "What is the difference between a politician who says Africa cannot do without imperialism and a writer who says Africa cannot do without European languages?"

Sustainable globalization requires that we not only use our natural resources to feed the factories of international plants. Sustainable globalization invokes the African continent to be an active participant in the languages that convey and share world class innovations and inventions. Languages that carry the masses into an international arena without fear of identifying themselves or being identified as Africans are languages that facilitate speakers to become global citizens. Such languages will transport both their speakers and their culture for the holistic benefit of the world. African leaders would do the continent a favor if they could focus on linguistic and cultural contribution to the global market. Engaging all the people of a nation instills the spirit of nationalism and patriotism. Once their languages and culture are appreciated they too can influence change as equal partners and they won't be threatened with regime changes.

While it is saddening to realize that Zimbabwe and many other African countries seem to enjoy doing business in foreign languages, it should be appreciated that their present predicament has its genesis in the 1884 Berlin Conference where the African continent was partitioned. This history has left an indelible mark on the African linguistic landscape decades after colonialism was conquered. To redress the situation, it is imperative for African governments to embark on social transformation so as to access linguistic and economic freedoms. The language used in any country defines the state of 
affairs for example, during colonialism Africa was divided into Lusophone, Francophone and Anglophone Africa. If the status quo remains it simply means that socio-economic liberation is far from the African states.

Because the focus of this article is language and culture in the global village, we proceed to talk about the language of educational instruction. This is because language provides selective access to economic participation and occupational mobility, in the education and development of people's knowledge, skills, norms and values. Mawasha (1988 as cited in Webb 2002 p.12) remarks that "...to be educated and trained means having acquired knowledge and expertise mainly through the medium of English." Prah (2005) maintains that knowledge transfer occurs in the language(s) of the masses, the language in which the people are most creative and innovative, the languages, which speak to them primevally in their hearts and minds. These are the languages they dream and cry in. A language that speaks to the heart unlocks the intellect of the learner for greater creativity and innovation.

Speaking about the Zimbabwean situation, Mudenge confirms that “...the language policy adopted at independence and enshrined in the Education Act enhances English as the language of education and business administration at the expense of other languages" (The Sunday Mail, 2009). This presents an amazing paradox of development in that those who claim the voice of vision about wisdom and development can only dream in foreign languages. Is this not a tactful way of excluding a majority of the indigenous populace from active socio-economic participation? Does development only occur when communication is through non-African languages? Whose culture is transmitted during the learning process? Although the new constitution of Zimbabwe has lifted the status of indigenous languages this is only as far as them being subjects of study in the school curriculum not as media of instruction.

Bamgbose (2000 pp.58-59) mentions that UNESCO experts who met in Paris in 1951 to consider language as a medium of instruction concluded that:

On educational grounds, we recommend that mother tongue be extended to as late a stage in education as possible. In particular, pupils should begin their schooling through the medium of the mother tongue, because they understand it best and because to begin their school life in the mother tongue will make the break between home and school as small as possible.

The medium of instruction is viewed to have a strong bearing on how the learner will adjust to school life as it either provides a smooth handover-takeover from the home to the school system or a rough grab that might result in frustrating the learner. The 1951 UNESCO report actually recommended on psychological, social and educational grounds that children be taught in a language they know effectively, which will normally be the mother tongue of the children (Webb 2002 p.192). 
The late former President of South Africa Nelson Mandela once said "If you talk to a man in a language he understands, that goes to his head; if you talk to him in his language that goes to his heart." Language is a key component to a people's culture. It is closely interwoven with culture so there is no way the two can be divorced without compromising the other. English carries the English culture while Ndebele will carry Ndebele culture. For a language to survive, it must be used for a wide range of functions otherwise it begins to wither and die.

The language used for education purposes should be a language capable of opening communication barriers. If a language creates a host of "misunderstoods" then the "barriers" cannot be easily cleared. Hubbard (1992 p.42) identifies among other barriers to study, the misunderstood word as the third and most important barrier to study. The barrier clearly demonstrates the importance of language in the comprehension of concepts in the learning process. In the global world, what Africans require is not knowledge of a global language; rather they need understanding of global economics, politics, technological developments in our own languages for us to also participate. If participation is regulated by understanding then a language that removes "misunderstood" is the language that will engage people to play their part as equal partners in the global space. For Africans, it is their indigenous African languages that can unlock the doors to global citizenship.

Prah (2001b in Brock-Utne \& Hopson 2005 p.27) postulates that language of education is the language of hegemony and power. He asserts that knowledge is accumulated and deposited in the language of instruction and where language of instruction is the same as mother tongue it gives confidence to a people with respect to their historical and cultural baggage. The assertion resonates to the fact that knowledge transfer takes place in the language in which the masses are most creative and innovative. Linked to that, Mutasa (2004 p.38) educates and advises that '...to guarantee success, knowledge and skill must be disseminated in languages easiest for millions to understand.' However, Bamgbose (1991 p.69) clearly articulates the dilemma of African nations. He notes that African nations simply carry on the legacy of the policies of the past. Mother tongue instruction should be promoted to enhance concept formation and include a majority of the indigenous learners as well as make cultural and emotional transfer from home to school easy. However, the illusions arising from colonial legacy impede the adoption of African languages as languages of educational instruction.

Ngara (1982 p.23) while referring to Zimbabwe had earlier pointed out that for many Africans to be educated was equivalent to acquisition of a European language thereby corroborating Rubanza's argument. Rubanza (1996) argues that for some;

English $=$ Education

English $=$ School uniform because you take it off when you go home. 
Rubanza insists that African development is impossible without the use of African languages, (Prah 2002 p.44). The authority maintains that ethnic languages enable those who interact to make relevant connections with their lives beyond the school. Observations have revealed that many Zimbabweans still hold the belief that to be educated is to acquire knowledge through the medium of English. While failing to plan is planning to fail, failing to use indigenous languages as media of educational instruction is planning for exclusion from global socio-economic and political affairs. Failure to use indigenous languages ultimately results in cultural exclusion which replicates into low esteem. Low esteem affects the innovative and creative potential. A situation where a speaker is thrown into an arena where they cannot express their thought in their indigenous languages reduces them to objects that can only be acted upon by their environment.

Choice of language of instruction is influenced not by pedagogical factors but other factors like perceived status of the language. English is perceived to be more powerful and to provide access to information and technology. NEPI (1992 p.13 cited in Bamgbose 2000 p.93) confirms that mother tongue is associated with inferior education offered under the Ministry of Bantu Education in apartheid South Africa. English is therefore perceived as a gateway to better education. As a result of the colonial legacy, policy on African languages as a medium of instruction has been notoriously unstable (Bamgbose, ibid). However, Adams and Mayes (1998) remark that we should not happily and proudly put our children through education processes, which render them illiterate and even "unoral" in our African languages.

In the view of this article, a language that helps the learner grasp new knowledge, apply the new knowledge to real life situation beyond the classroom and if possible share the new knowledge with immediate community is a language opening doors for participation in the global village. The language encourages development and transfer of knowledge in a way that does not leave learners alienated from their immediate and the global environment. Such a language will not be equated to school uniform that can be taken off when school is over. In any case the whole purpose of education is not to educate so that people can put aside what they will have learnt when school is over. The purpose of education is to equip the learner with skills for life that can be applied throughout the process of living be it in the immediate environment or global environment.

The world over education prepares its recipients for the workplace hence the language of educational instruction is pivotal to perceptions about the language of the workplace. Development occurs only when people are capable of harnessing their languages in a practical manner for socio-economic communication. This is realized when language as culture produces and reflects human beings communicating with each other in the struggle to create wealth and control it (Ngugi, 1994). The colonizers used formal education and foreign literature to further remove the African child from his/her environment. Formal education resulted in the creation of elites of leisure. Ngugi (1994 p.12) asserts that 'language and literature were used to take people further and further 
away from their culture, themselves to other selves, from their world to other worlds.' $\mathrm{He}$ emphasizes that the language of education was no longer the language of African culture. For this reason, African languages have not been viewed as communication and carrier of culture (Ngugi, 1994) or tools capable of positioning their speakers in socio-economic dynamics of life.

The language of communication influences the appreciation of content, transfer and application of knowledge. Just as the language of literature influences its appreciation by readers, the language of instruction is critical. Related to this Kole Omotoso (1987 cited by Anyidoho, ibid) observes that the banning of Ngugi's Matigari was a result of the language used. Security officers who collected copies of Matigari warned the publishers not to reprint "in Kikuyu", but were not bothered by the English version. The Kikuyu version was more "dangerous" in the views of the government for it mobilizes peasants and workers for social transformation.

Ngugi's case aptly conveys the role of African languages and literature in education as a vehicle for social transformation and global inclusion. African literature will conscientize the masses instead of a fraction of the elite, giving pointers to challenges in the physical, historical, economic and socio-political environments of the learners. According to Justice (2002) mother tongue language is a meaningful complement to the healing process of decolonization and indigenous empowerment hence African languages can restore and boost confidence ushering their speakers to become global citizens.

\section{Understanding language and culture: the Zimbabwean Experience}

Language is the intangible embodiment of the intangible cultural traditions of its speakers. Language and culture oil the software for development of any society and influence their inclusion or exclusion in becoming global citizens due to the fact that philosophy is resident in cultural experiences that are expressed through language.

The biblical Tower of Babel aptly illustrates how language can slow down development demonstrating the significant socio-economic and political role language can have to human development. Language was used to alienate the Africans to lose touch with their roots so as to prevent communal rebellion during slave trade. Anyidoho (1992 p.55) cites Madhubuti (1984 p.123) asserting that "...for without language, one cannot express the indigenous self, and therefore has nothing to express other than the selves of others in their languages." In pre-colonial Zimbabwe, language was not just a communicative tool or a mode of cultural transmission, but as rightly noted by Kerr (1973 p.90) it was “... a powerful instrument by which not only individuals may express their personality, but groups may also identify their collective consciousness" and claim their space as global citizens.

The language and culture of a people define how they will interact with each other, their philosophy of life as well as their values. As a way of illustration, the paper will select 
examples from the Shona community of Zimbabwe. Brelsford (1938 p.16) postulates that life as lived by the Shona people "... is sanctioned by tradition, guided by taboos and fear of the supernatural therefore it is a life of compliance and servitude to a ready-made philosophy." Of significance is that language defines people's philosophy, their culture and beliefs.

It was against this background that this researcher developed the Dandaro Model which was pilot tested on training of farmers. To tap the best out of the new farmers, instead of alienating learners from their community, the model takes learning to the communities in their languages observing their cultural beliefs but introducing modern farming methods blending them with what the communities already know. Findings and observations from two pilot studies conducted in Marondera (Igava Farm) and Bindura (Nyamakura Farm) were that the use of indigenous languages instilled confidence to the extent that "ordinary" village people actively participated and engaged without shying away from using their languages even in meetings that were academically engaging on farming and development.

In interviews conducted to establish use of Zimbabwean indigenous languages for economic empowerment, one of the interviewees asserted that: 'Language is instrumental in that when you do things in your language you can lay claim to them' (Mavesera, 2009 p.127). Another interviewee, a lecturer, who had once worked for Amalgamated Motor Corporation (AMC), demonstrated that in an industrial set up a 'misunderstood' instruction can lead to dangerous incidents or delays or extra expenses (ibid, p. 128). The flip side of using indigenous languages is that it is empowering when labour negotiations are conducted in indigenous languages (ibid, p. 129). Mavesera (2009 p. 111) established that:

To influence behaviour change and include a majority of the locals we need convergence in their languages, so that the projects are not alien to them for example, new methods of farming if communicated in indigenous languages can easily be learned/communicated to the semi-literates who form the majority of Zimbabwe's population.

Behaviour change can be easily regulated when learners are in their natural situation. Global concepts can still be learnt while people are using their indigenous language. The Dandaro model is an effort towards conserving the African traditional culture and supports Lee's (ICOM NEWS 2004 p.6) castigation of this linguistic and cultural death when he says "...in this technological age, we are losing true knowledge, true wisdom, true living. And we are losing all this while being inundated with information. As argued by Professor Tenebe in his keynote address at the Zimbabwe Open University International Research Conference, "Sustainable development obtains only when Africans use their inclusive education to solve their own problems. They can only use knowledge from other countries to fine tune their problem-solving capacities." (July 25, 2013). 
Referring to pre-colonial Zimbabwe, Burbridge (1938) degrades and undermines the precolonial Zimbabwean religion of the Shona as he reports that Rhodesia is infested with various spirits that make evangelism almost impossible. He claims that he witnessed the Hartley District police post struck twice by a bolt of lightning while the mine was flooded on three occasions by the displeasure of the spirits that the Shona view as their rightful owners, the guardians of the land. The spirits are said to reside in mines, mountains, vleis and in perennial springs. No person in his sane mind would have had the courage to venture into the forests, rivers, vleis and in perennial springs alone out fear of these spirits (Achebe, 1958), as a result environmental preservation was maintained. With destruction of these beliefs came the destruction and degradation of the environment in Zimbabwe and Africa as a whole. Respect of traditional setups has seen learners in the pilot projects addressing issues of the environment at theory lessons and in practice.

In a nutshell, the pilot projects have shown that for effective engagement as global citizens, what is required is perception and understanding of challenges faced in the global socio-economic sphere. Understanding is enhanced in languages that speak to the heart - indigenous languages.

\section{Challenges}

While it is possible to include African languages, and culture the hurdles that slow and or prevent inclusion on the global language landscape are wide and varied. Triandis (1971) cited in Okombo (1999 p.591) declares that: "We have the technical knowledge to change the world, but we do not have the attitude to bring the change." The greatest obstacle is decolonizing the mind from centuries of viewing African languages as backward and unable to deliver modern technical knowledge. It is all in the mind since all languages can be developed. Africans should take a leaf from the English who developed their language to what it is today against the backdrop of Latin and French languages. Had the English not changed their attitude Latin would still be the global language.

Global languages such as English acquired that status because of the economic status of their speakers. For as long as the African continent continues to be a recipient of global aid, the inhabitants will continue to use their donors' language while their languages are relegated to the classroom only as subjects of study and African culture downgraded as primitive and poor. The contribution of African academics will continue to be overshadowed for lack of ethnic voice. In Zimbabwe colonialism destroyed the African identity to an extent that many would rather speak like the English, eat like the English and dress like the English. It is even pathetic to witness the rush to speak Chinese languages because the Chinese are an economic force to reckon with due to the look East policy. 
There is also a challenge related to costs that will be incurred should African languages be made media of educational instruction. In a country where people are struggling to satisfy physiological needs such as food, shelter and security, truly language would be considered an esteem need and considered last according to Maslow's hierarchy of needs. According to the 1990 adapted hierarchy of needs, language as culture would qualify as a self-actualization need that falls under category 7. All other needs would have to be met before consideration of language needs. These challenges coupled with colonial legacy continue to attract Africans to use foreign languages ahead of indigenous languages. But is it sustainable to continue using foreign languages?

\section{Parting Shot}

In spite of all these the voice of reason and vision dictates that Africa needs strong willed linguists, economists and citizens who should use their strength in diversity as an asset to contribute to global sustainable development. Ngugi (1994 p.24) questions, "What is the difference between a politician who says Africa cannot do without imperialism and a writer who says Africa cannot do without European languages?" It should be appreciated that no freedom was handed in a silver platter more so if it is linguistic freedom. Before talking about cultural exchange it is wise to embrace all languages of the world this will present the rich tapestry that exists in a multi-cultural and multi-lingual environment.

The proposal that this article is making is that no language should be annihilated. Politicians, economists, industrialists, educationists and all sectors can ignore language planning at their own peril. For Africans to become global citizens they should appreciate their linguistic and cultural strength in diversity instead of holding falsehoods that their languages cannot be used as media of communicating modern technical knowledge. Before becoming a global citizen, linguistic identity, freedom and esteem is critical since language is the soul of any nation. As a starting point, Africa can establish lingua-franca while she accommodates diversity so that she taps into the cultural milieu of the whole continent. According to Perez de Cuellar (1994:179),

A people's spoken and written language is perhaps the most important cultural attribute... Language policy, like other policies has been used as an instrument of domination, fragmentation and reintegration into the ruling political structure.

Basing on Perez de Cuellar's views about language and the relationship between language, culture and literature, it can be argued that language and culture have a potential to integrate people to become global citizens.

\section{Conclusion}

The paper has argued language is a critical success factor for one to become a global citizen. Mother tongue language if used as a media educational instruction has to 
enhance potential for learners to make relevant connections with their lives beyond the school. Two case studies have demonstrated that it is possible to use African languages to boost self-esteem and increase opportunity so that Africans participate as equal citizens of the globe. Global citizens care about the existence of others and the generations to come. Knowledge and Information are critical factors in promoting global citizenship and it is more important to include the masses so as to avoid global catastrophes. The languages which speak to the heart are the languages that facilitate global citizenship.

\section{References}

Achebe, C. 1958. Things Fall Apart. London: Heinemann.

Adams, A.V. and Mayes, J.A. 1998. African Literature and Africa's Development. Asmara: Africa World Press.

Anyidoho, K. 1992. "Language and Development Strategy in Pan-African Literary Experience". In Research in African Literatures Volume 23 p 45 - 63.

Bamgbose, A. 1991. Mother Tongue Education: The West African Experience. Paris: The UNESCO Press.

Bamgbose, A. 2000. Language and Exclusion: The Consequences of Language Policies in Africa. Hamburg: Lit Verlag Miinster.

Brelsford, V.1938. The Philosophy of the Savage. The Southern Rhodesia Native Affairs Department Annual (NADA), Volume 35, 1938 pp 62-65.

Burbridge, S.J. 1938. In Spirit-Bound Rhodesia. In Farquhar,J.H.(ed) The Southern Rhodesia Native Affairs Department Annual (NADA), Volume 35. Salisbury: Southern Rhodesia Native Affairs.

Brock - Utne, B. and Hopson, R.K. (Eds.) 2005. Language of Instruction for African Emancipation: Focus on Postcolonial Contexts and Consideration. Cape Town: CASAS.

Hubbard, L.R. 1992. Study Skills for Life. Pretoria: Education Alive Africa.

Justice, D.H. 2004. Conjuring Marks: Furthering Indigenous Empowerment through Literature. In American, Indian Quarterly Berkeley: Winter 2004 Vol 28, Iss. 1/2 p 3,9 .

Kerr, D.H. 1976. Educational Policy: Analysis Structure and Justification. New York: David Mackay.

Madhubuti, J. 1984. Earthquake and Sunrise Missions: Poetry and Essays on Black Renewal. Chicago: Third World Press. 
Mavesera, M. 2009. Empowerment through Language: Possibilities of using African Languages and Literature for socio-cultural and economic development in Zimbabwe. PhD thesis, University of South Africa.

Muindi, M. 2002. Some African Languages on Death List. All Africa, Com Website 20.04.2004.

Mutasa, D.E.2004. People Speak: Language Policy and Language Use in South Africa. Pretoria: Simba Guru Publishers.

Mutasa, D.E. 2006. African Languages in the $21^{\text {st }}$ Century: The Main Challenges. Pretoria: Simbaguru Publishers.

Ngara, E.A. 1982. Billingualism Language Contact and Planning: Proposals for Language Use and Language Teaching in Zimbabwe. Gweru: Mambo Press.

Ngugi wa Thiongo, 1994. Decolonising the Mind. Harare: Zimbabwe Publishing House.

Okombo, D.O.1999.Towards a Strategy for Changing Attitudes to Indigenous African Languages, in Comparative Perspectives on Language and Literacy: Selected Papers from the Work of Language and Literacy Commission of the $10^{\text {th }}$ World Congress of Comparative Education Societies, edited by L.Limage. Dakar, Senegal UNESCO-BRAEDA.

Perez de Cuellar, J. 1994. Our Creative Diversity. Report of the World Commission on Culture and Development. France: Egoprim.

Prah, K.K. 1995. African Languages for the Mass Education of Africans. Bonn: German Foundation for International Development Education, Science and Documentation Centre.

Prah, K.K. 2002. Rehabilitating African Languages: Language Use, Language Policy and Literacy in Africa. Cape Town: the Centre for Advanced Studies of African Society.

Roy-Campbell Z.M. 2006. The State of African Languages and the Global Language Politics: Empowering African Languages in the Era of Globalization. In Selected Proceedings of the 36th Annual Conference on African Linguistics, ed. Olaoba F. Arasanyin and Michael A. Pemberton, 1-13. Somerville, MA: Cascadilla Proceedings Project. www.lingref.com, document \#1401. pp. 1-13.

Rubanza, Y.I. 1996. Can a Three-tier Language Policy Work in Tanzania? A New Perspective: UFAHAMU: Journal of the African Activist Association Vol 24 No. 1 p 82-98.

Skutnabb - Kangas, T. 1998. "Human Rights and Language Wrongs - A Future for Diversity?" In Language Sciences, Vol 20 No. 1 pp. 5 - 27.

Skutnabb - Kangas, T. 2000. Linguistic Genocide in Education or Worldwide Diversity and Human Rights? Mahwah: N.J.L. Erlbaun Associates. 
Uju, C.C. 2008. Language Science, Technology, and Mathematics TM and Poverty Alleviation in Africa: A Case of Nigeria in Zimbabwe Journal of Educational Research Volume 20(1): 22-29.

Webb, V. 2002. Language in South Africa the Role of Language in National Transformation, Reconstruction and Development. Amsterdam: John Benjamins Publishing Company. 